\title{
SEASONAL CHANGES OF THE CONDITION INDICES AND HAEMOCYTE COUNTS OF THE AUSTROPOTAMOBIUS TORRENTIUM POPULATION IN KRALJEVEC STREAM, CROATIA
}

\author{
A. LUCIĆ, R. ERBEN
}

Department of Zoology, Faculty of Science, Rooseveltov trg 6, 10000 Zagreb, Croatia E-Mail: andreja@zg.biol.pmf.hr

Reçu le 19 octobre 2004

Accepté 15 mars 2005

Received October 19, 2004

Accepted March 15, 2005

\begin{abstract}
The stone crayfish, Austropotamobius torrentium (Schrank, 1803) is one of the four native European crayfish living in Croatian freshwaters. Kraljevec Stream is situated on the southern slopes of Medvednica Mountain (north-west Croatia) at $400 \mathrm{~m}$ above-sea level. Our research was carried out for one year, from May 2003 to April 2004. During the study period water temperature varied between 2 to $17.2^{\circ} \mathrm{C}$, alkalinity between 100 and $200 \mathrm{mg}$ $\mathrm{CaCO}_{3} / \mathrm{L}$, the mean oxygen concentration and $\mathrm{pH}$ was $12.1 \mathrm{mg} / \mathrm{L}$ and 8.3 , respectively. Crayfish were trapped by baited hand made traps, which were secured in a stream current with the stones and roots of the surrounding trees. We caught 100 crayfishes, 68 males and 32 females. Hemolymph was sampled 10 to $15 \mathrm{~min}$ after the catch. EDTA anticoagulant was used to prevent hemolymph coagulation and $10 \%$ formalin was used to fix haemocyte for differential counts. Each month five or six specimens of each sex, if possible, were sacrificed and hepatosomatic, gonadosomatic and muscle indices were measured. We found statistically significant differences in hepatosomatic and gonadosomatic indices between months and between sexes. Muscle indices were significantly different between males and females. The average total haemocyte counts were $7.6 \times 10^{5} \mathrm{cells} /$ $\mathrm{ml}$ and $6.5 \times 10^{5} \mathrm{cells} / \mathrm{ml}$ hemolymph for males and females, respectively. The average hyalinocyte, granulocyte and semigranulocyte ratio was $77: 14.5: 8.5 \%$. There were no statistically significant differences in total haemocyte counts between months and between sexes.
\end{abstract} Croatia.

Key-words: Austropotamobius torrentium, condition indices, haemocyte counts,

\section{CHANGEMENTS SAISONNIERS DES INDICES DE CONDITION ET DES DÉNOMBREMENTS D'HÉMOCYTES DANS LES POPULATIONS D'AUSTROPOTAMOBIUS TORRENTIUM DU RUISSEAU DE KRALJEVEC, CROATIE}

\section{RÉSUMÉ}

L'écrevisse pierre ("écrevisse des torrents en français"), Austropotamobius torrentium est l'une des quatre écrevisses natives européennes vivant dans les eaux douces croates. Le ruisseau de Kraljevec est situé sur le versant sud de la montagne de Medvednica (Nord-Ouest de la Croatie) à 400 mètres au-dessus du niveau de la mer. Notre travail de recherche s'est déroulé sur un an, de mai 2003 à avril 2004. La température a varié entre $2^{\circ} \mathrm{C}$ et $17,3^{\circ} \mathrm{C}$, la concentration moyenne d'oxygène était de $12,1 \mathrm{mg} / \mathrm{L}$, le $\mathrm{pH}$ 
moyen 8,3 et l'alkalinité entre 100 et $200 \mathrm{mg} \mathrm{CaCO}_{3} / \mathrm{L}$. Nous avons capturé les écrevisses au moyen de pièges apâtés faits à la main, protégés du courant au moyen des pierres et des racines des arbres environnants. 100 écrevisses ont été capturées, 68 mâles et 32 femelles. Les échantillons d'hémolymphe ont été prélevés 10 à 15 minutes après la capture. L'anticoagulant EDTA a été utilisé pour empêcher la coagulation de l'hémolymphe et une solution de formaline à $10 \%$ pour fixer les hémocytes en vue du dénombrement. Chaque mois 5 à 6 animaux ont été sacrifiés pour mesurer les indices hépatosomatiques, gonadosomatiques, et musculaires. Nous avons trouvé des différences statistiquement significatives dans les indices hépatosomatiques et gonadosomatiques des deux sexes et selon les mois. Les indices musculaires étaient considérablement différents entre mâles et femelles. Le nombre total moyen d'hémocytes pour les mâles était de 7,6 × $10^{5}$ cellules $/ \mathrm{ml}$ d'hémolymphe et pour les femelles de $6,5 \times 10^{5}$ cellules $/ \mathrm{ml}$. Le ratio moyen de hyalinocytes, granulocytes et semigranulocytes était de $77: 14,5: 8,8 \%$ respectivement. II n'y a pas de différence statistiquement significative entre les nombres totaux d'hémocytes des différents mois et entre les sexes.

Mots-clés : Austropotamobius torrentium, indices de condition, dénombrement d'hémocytes, Croatie.

\section{INTRODUCTION}

The stone crayfish, Austropotamobius torrentium (Schrank, 1803) is one of the four native European crayfishes living in Croatian freshwaters and is protected by law nationally (NARODNE NOVINE 72/94; NARODNE NOVINE 76/98). This species is well adapted to lower water temperature and velocities typical for streams at higher altitudes (BOHL, 1987). A. torrentium is not as well investigated as other species of Astacidae family in Europe and recent research of this species in Croatia contributed to the knowledge on its biology and ecology (BOHL, 1987; LAURENT, 1988; MAGUIRE, 2002). Information on organosomatic indices and haemocyte counts in this species are lacking although some Croatian authors measured muscle and hepatopancreas participation in the body weight of $A$. torrentium (OBRADOVIĆ, SEKULIĆ and RAC, 1988).

Changes in the relative size of hepatopancreas (hepatosomatic indices) and its moisture content are used to evaluate nutritional status, as well as crayfish condition and exposition to environmental stress (MANNONEN and HENTTONEN, 1995). The annual cycle of freshwater crayfish can be characterized by changes in hepatopancreas energy content, which serves as the main source for the ovarian development, growth and moulting of the crayfish (HUNER, KÖNÖNEN and LINDQVIST, 1990; MANNONEN and HENTTONEN, 1995; JUSSILA, 1997). KYOMO (1988) studied the relationship between gonad indices and hepatopancreas indices in males and females of Sesarma intermedia (De Haan, 1935) while YAMAGUCHI (2001) investigated changes of hepatopancreas and testis indices during the reproductive period of male fiddler crabs, Uca lactea (De Haan, 1835). If tail muscle is considered as a storage site of the energy reserves, tail muscle to body weight radio and tail moisture levels can be considered as a condition index. Muscle indices were used as a measure of condition in dietary studies (FOTEDAR, 1998; TSVETNENKO et al., 1999), as well as in comparative studies of morphology and edible tissues of two commercially important crayfishes (HUNER, LINDQVIST and KÖNÖNEN, 1988).

Changes in total haemocyte counts were used as an indicator of stress caused by injuries (JONES, 1999), transport conditions (JUSSILA et al., 1999) or environmental contamination (LE MOULLAC and HAFFNER, 2000; YILDIZ and BENLI, 2004). Also, JOHANNSON et al. (2000) noticed that total haemocyte counts change during the moulting period. Published data on total haemocyte counts in the Astacidae family are lacking while there are some data on haemocyte counts in other species belonging to Decapoda (CORNICK and STEWART, 1978; JUSSILA, 1997; YILDIZ and BENLI, 2004). 
It is generally accepted that in Decapoda there are three basic types of haemocytes: hyalinocytes, semigranulocytes and granulocytes (WOOD and VISENTIN, 1967; ANDERSON, 1981; BAUCHAU, 1981; MARTIN and GRAVES, 1985; MARTIN and HOSE, 1992) and VACCA and FINGERMAN (1983) described changes of differential haemocyte counts during moulting period.

As there are almost no data on organosomatic indices of $A$. torrentium the aim of this research was to measure these indices and describe their seasonal changes. Standard condition indices (hepatosomatic, gonadosomatic and muscle indices) were chosen and compared between months and between sexes. Moreover, there are no data on total and differential haemocyte counts in A. torrentium at all so these parameters were measured as well and compared between seasons and between sexes. Kraljevec Stream is located in the protected area of the Nature Park Medvednica, which is close to the capital city of Croatia, Zagreb and is very popular destination of the urban population. As many populations of $A$. torrentium in that area were vanished, mainly because of anthropogenic activities, research was made on a small sample size, which was approved by the management of the Nature Park.

\section{MATERIAL AND METHODS}

Stone crayfish individuals were trapped from the Kraljevec Stream located on the southern slopes of Medvednica Mountain (north-west Croatia) at $400 \mathrm{~m}$ above the sea level in a beech and chestnut-tree forest. Baited hand-made traps were applied for one year from May 2003 to April 2004. Physical and chemical parameters of the stream were measured (temperature, oxygen, alkalinity, $\mathrm{pH}$ ). Hemolymph of all crayfish caught was sampled 10 to 15 minutes after catch. For total haemocyte counts hemolymph was diluted with EDTA based anticoagulant $(0.49 \mathrm{M} \mathrm{NaCl}, 30 \mathrm{mM}$ trisodium citrate, $10 \mathrm{mM}$ EDTA), the hemolymph and anticoagulant ratio was 1:1. Counts of un-coloured cells were made in Neubauer chamber at $50 \times$ microscope magnification (VÁSQUEZ et al., 1997). Each month, hemolymph from a few randomly chosen crayfish was sampled for differential haemocyte counts. For that purpose, hemolymph was diluted with $10 \%$ formaline at $3: 1$ ratio and haemocytes were fixed $2-3$ hours on $6^{\circ} \mathrm{C}$. Afterwards, smears were made and stained with the WRIGHT stain, which stained the granule of granulocytes in orange-red and the granule of semigranulocytes in green-blue. On each of two randomly chosen smears, 200 hemocytes were counted and the ratio of three different cell types was calculated (according to MIX and SPARKS, 1980).

We had no catch in traps during January and February and moreover, females were caught only from May until September. Therefore, the statistical analysis was made only for that period when crayfish were active. Each month, 5 or 6 males and females were sacrificed and dissected within 20 to 24 hours of their collection. Hepatopacreata, gonads and tail muscle were removed, placed in a foil cups and weighed. Organs were then dried at $80^{\circ} \mathrm{C}$ for 24 hours and weighed again. Organosomatic indices were expressed as wet organosomatic index $\left(\mathrm{Oi}_{\text {wet }}\right.$; equation 1$)$ and organ moisture content $(\mathrm{OM}$; equation 2$)$ (JUSSILA, 1997).

$\mathrm{Oi}_{\text {wet }}=\mathrm{W}_{\text {wo }} \times 100 / \mathrm{W}_{\mathrm{t}}$ and (2) OM $=\left(\mathrm{W}_{\text {wo }}-\mathrm{W}_{\text {do }}\right) \times 100 / \mathrm{W}_{\text {wh }}$, where: $\mathrm{W}_{\text {wh }}=$ weight of wet organ (g); $W_{t}=$ total weight of crayfish (g); and $W_{d o}=$ weight of dry organ (g)(1)

Results were expressed as mean values. The normality of data distribution is tested by Shapiro-Wilks'W test and afterwards differences in condition indices between sexes and between months were analysed using nonparametric analysis of variance (KRUSKALWALLIS test). SPEARMAN correlation test was used for correlations between the weights of the organs and the whole animal. Parametric one-way analysis of variance (ANOVA) was used to test difference in differential haemocyte counts between sexes and between 
months. We were using Statistica 5.0 for statistical analysis. Results were considered statistically significant at $\mathrm{p}<0.05$.

\section{RESULTS}

We caught altogether 100 crayfish, 68 males and 32 females. The sex ratio (males to females) was 2.1:1 $\left(\mathrm{S}_{0}=0.36\right)$. The average male weight was $18.8 \pm 1.3 \mathrm{~g}$, it varied between 2.9 and $4.6 \mathrm{~g}$ while the average female weight was $12.9 \pm 1 \mathrm{~g}$ and it varied between 5 and $26 \mathrm{~g}$. Total lengths (TL) of males range between 4.1 and $9.2 \mathrm{~cm}$, the mean was $7.0 \pm 0.1 \mathrm{~cm}$ and the total length of the females ranged between 2.7 and $8.8 \mathrm{~cm}$ with its mean value at $6.7 \pm 0.2 \mathrm{~cm}$. Ten males less than $5 \mathrm{~cm}$ TL and three females less than $6 \mathrm{~cm}$ TL were excluded from the analysis. Analysis was made for males caught from March until December (ten months analysed) and for females caught from May until September (five months analysed).

The average annual temperature of the stream was $9.4 \pm 1.6^{\circ} \mathrm{C}$, its oxygen concentration $12.1 \pm 0.8^{\circ} \mathrm{C}, \mathrm{pH} 8.3 \pm 0.1$ and its alkalinity varied between 100 and $200 \mathrm{mg} \mathrm{CaCO}_{3} / \mathrm{L}$.

Stone crayfish males had a higher relative hepatopancreas weight $\left(\mathrm{Hi}_{\text {wet }} 6.7-7.2 \%\right)$ and lower moisture content (HM 45-64\%) at the beginning of the year (March, April) and during the mating period in October when $\mathrm{Hi}_{\text {wet }}$ was $6.6 \%$ and $\mathrm{HM}$ was $61 \%$ (Figures 1 and 2). During moulting (from June until September) the $\mathrm{Hi}_{\text {wet }}$ of males varied between 2.4 and $5.7 \%$ and $\mathrm{HM}$ varied between 67.3 and $83 \%$ (Figures 1 and 2). Females had lower $\mathrm{Hi}_{\text {wet }}$ in September (4.6\%) than during moulting when it was around $5.6 \%$. The moisture content of hepatopancreas in females decreased from June (83\%) to September when $72 \%$ of moisture was determined.

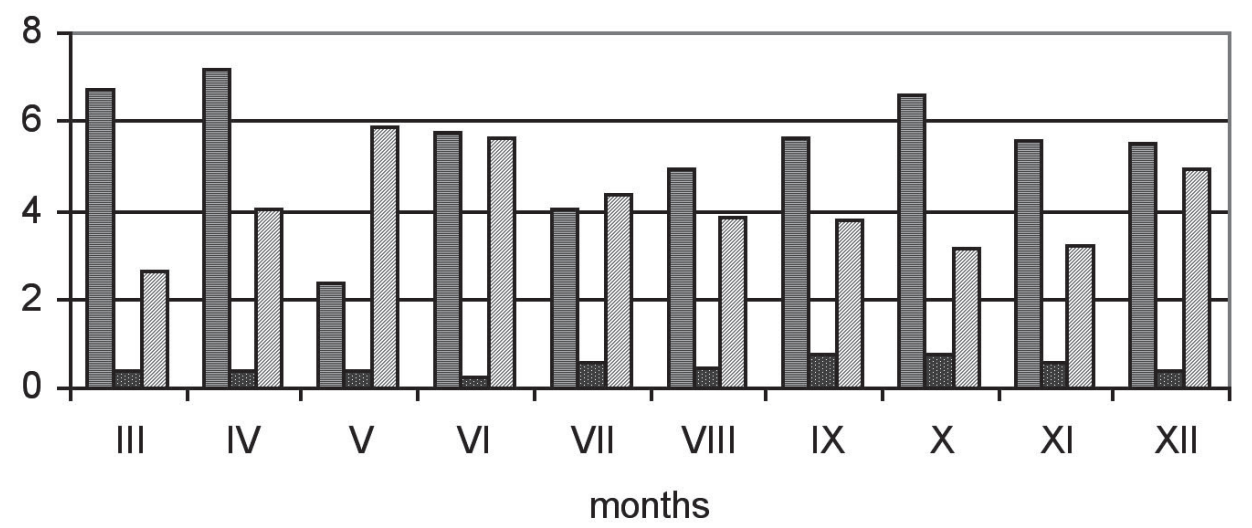

目 Hiwet\% Giwet\% 圆 Miwet\%

\section{Figure 1}

Mean values of relative weight of hepatopancreas $\left(\mathrm{Hi}_{\text {wet }} \%\right)$, gonads $\left(\mathrm{Gi}_{\text {wet }} \%\right)$ and tail muscle $\left(\mathrm{Mi}_{\text {wet }} \%\right)$ of Austropotamobius torrentium males from March to December, in Kraljevec Stream, Croatia.

Figure 1

Valeurs moyennes du poids relatif de l'hépatopancreas $\left(\mathrm{Hi}_{\text {poids }} \%\right)$, des gonades $\left(\mathrm{Gi}_{\text {poids }} \%\right)$ et du muscle de la queue $\left(\mathrm{Mi}_{\text {poids }} \%\right)$ d'Austropotamobius torrentium mâle de mars à décembre, dans le ruisseau Kraljevec, Croatie. 


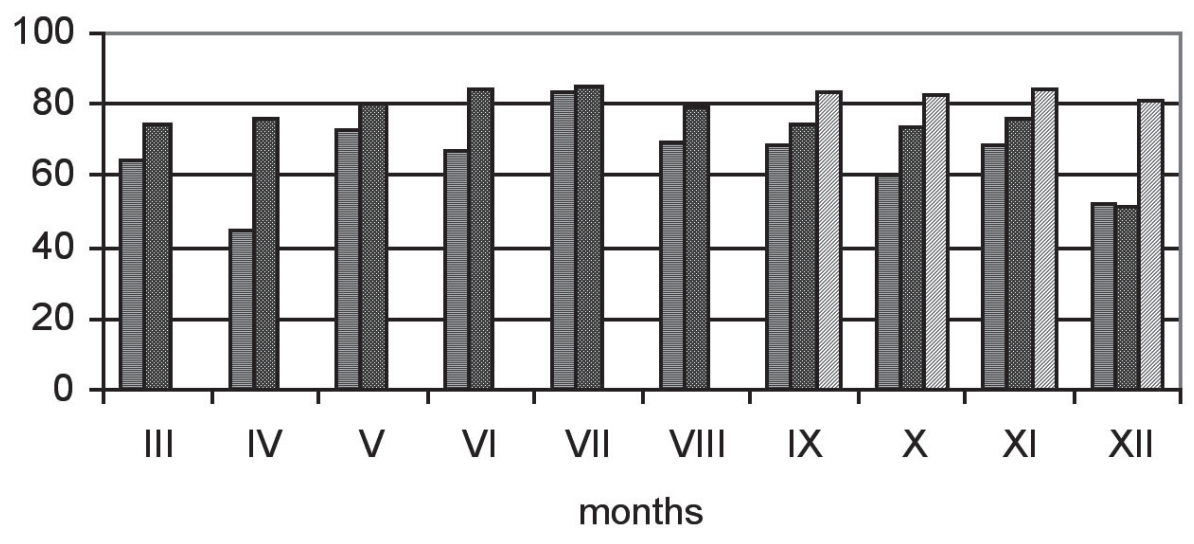

$\mathrm{HM} \% \mathrm{GM} \%$ 四 $\mathrm{MM} \%$

\section{Figure 2}

Average moisture content of hepatopancreas (HM\%), gonads (GM\%) and tail muscle (MM\%) of Austropotamobius torrentium males from March to December, in Kraljevec stream, Croatia.

\section{Figure 2}

Humidité moyenne du contenu de l'hépatopancreas (HM\%), des gonades (GM\%) et du muscle de la queue (MM\%) d'Austropotamobius torrentium mâles de mars à décembre, dans le ruisseau Kraljevec, Croatie.

The relative weight of the ovaries gradually increased from May $\left(\mathrm{Gi}_{\text {wet }} 0.7 \%\right)$ until September $\left(\mathrm{Gi}_{\text {wet }} 6.4 \%\right)$ while the weight of testis increased from 0.4 to only $0.8 \%$ during the same period (Figure 1). The relative testis weight decreased from 0.8 to $0.4 \%$ from October to April (Figure 1). The moisture contents of the ovaries were the lowest in August and September; they varied between $43.7-58.5 \%$ while from May to July moisture content ranged between 80 and $90 \%$. The moisture content of the testis was the lowest in December (around 50\%) while from March to November varied between 73 and 85\% (Figure 2). While preparing to mate and during mating (from August to November) the moisture content of testis was lower than during moulting, it ranged between 75 and $80 \%$ (Figure 2).

The KRUSKAL-WALLIS test indicated statistically significant differences in all hepatosomatic and gonadosomatic indices between months $(p<0.05)$ (Table I). Males and females differed significantly in the hepatopancreas moisture content and wet gonad index (Table I).

Differences in the relative weight of the tail muscle between the months were close to statistical significance (KRUSKAL-WALLIS test; $p=0.0559$ ). In males, lower relative weights of the tail muscle were detected during the moulting and mating period (from July to November) (Figure 1). Tail muscle moisture content varied in males from 80 to $87 \%$ between September and December (Figure 2). In females, the tail muscle/body weight ratio gradually decreased from $8.9 \%$ measured in June to $7.5 \%$ measured in September. Females had a significantly higher tail muscle/body weight ratio than males (KRUSKALWALLIS test; $p=0.008^{*}$ ). The tail muscle/body weight ratio varied between 6.3 and $8.9 \%$ in females while it was between 2.7 and $5.9 \%$ in males.

Statistically significant positive correlation was found between the weight of the hepatopancreas, gonads, tail muscle and total body weight (SPEARMAN correlation test; 


\section{Table I}

Statistical analysis (Kruskal-Wallis test) of hepatosomatic and gonadosomatic indices of Austropotamobius torrentium compared between months and between sexes, in Kraljevec Stream, Croatia.

Tableau I

Analyse statistique (test de Kruskal-Wallis) des indices hépatosomatiques et gonadosomatiques d'Austropotamobius torrentium sur plusieurs mois et entre sexes.

\begin{tabular}{|c|c|c|c|c|c|}
\hline $\begin{array}{c}\text { Kruskal- } \\
\text { Wallis test }\end{array}$ & $\begin{array}{c}\text { Hepatosomatic } \\
\text { indices }\end{array}$ & $\mathrm{p}$ & $\begin{array}{c}\text { Gonadosomatic } \\
\text { indices }\end{array}$ & $\mathrm{p}$ & $\mathrm{F}$ \\
\hline \multirow{2}{*}{$\begin{array}{c}\text { Compared between } \\
\text { sexes }\end{array}$} & $\mathrm{Hi}_{\text {wet }}$ & 0.6398 & $\mathrm{Gi}_{\text {wet }}$ & $0.0003^{*}$ & 1 \\
\cline { 2 - 6 } & $\mathrm{HM}$ & $0.0101^{*}$ & $\mathrm{GM}$ & 0.0645 & 1 \\
\hline \multirow{2}{*}{$\begin{array}{c}\text { Compared between } \\
\text { months }\end{array}$} & $\mathrm{Hi}_{\text {wet }}$ & $0.0303^{\star}$ & $\mathrm{Gi}_{\text {wet }}$ & $0.0436^{\star}$ & 8 \\
\cline { 2 - 6 } & $\mathrm{HM}$ & $0.0219^{\star}$ & $\mathrm{GM}$ & $0.0088^{\star}$ & 8 \\
\hline
\end{tabular}

* Statistically significant difference.

* Différence statistiquement significative.

$r=0.605^{\star}, r=0.3812^{*}, r=0.672^{*}$, respectively). Correlation between hepatopancreas, gonads and tail muscle relative weight and total body weight were negative and statistically significant (SPEARMAN correlation test; $r=-0.387^{\star} ; r=-0.3812^{\star} ; r=-0.389^{\star}$, respectively).

Seasonal changes of the total haemocyte counts (THC) are presented in Figure 3. There were no significant differences in the THC between the months (KRUSKAL-WALLIS test; $p=0.3279$ ) or the sexes (KRUSKAL-WALLIS test; $p=0,4179$ ) although the mean THC was higher during the moulting period compared to the rest of the year (Figure 3 ). The average total haemocyte count was $7.6 \times 10^{5} \mathrm{cells} / \mathrm{ml}$ and $6.5 \times 10^{5} \mathrm{cells} / \mathrm{ml}$ hemolymph for males and females, respectively.

Differential haemocyte counts $(\mathrm{DHC})$ were not significantly different between males and females (ANOVA; hyalinocytes $p=0.6556$; granulocytes $p=0.519$; semigranulocytes $p=0.9854$ ). The average ratio of hyalinocytes, granulocytes and semigranulocytes was 77.6: 13.9: $8.5 \%$ in males, while a slightly different ratio, $76.5: 15: 8.5 \%$, was determinated in females. The ratio of all three-cell types was significantly different between months (ANOVA; hyalinocytes $\mathrm{p}=0.021295^{*}$; granulocytes $\mathrm{p}=0.001570^{*}$; semigranulocytes $\left.\mathrm{p}=0.033814^{*}\right)$.

\section{DISCUSSION}

Kraljevec Stream is, by its characteristics, an ideal habitat for the stone crayfish if compared with the description given by BOHL (1987). Physical and chemical characteristics are in accordance with the data previously reported as being optimal for this species (MAGUIRE, 2002). Crayfish population of the stream was estimated on 1218 individuals (between 1039 and 1 472) by mark-recapture method at the year 2002 (MAGUIRE, 2002). The absence of crayfish in traps during January and February is probably the result of very low water temperature (between 2 and $2.8^{\circ} \mathrm{C}$ ) while the absence of females from October to May indicated the period when they bear eggs. Increase in the water temperature in March $\left(4.4^{\circ} \mathrm{C}\right)$ induced the activity of crayfish as it was previously described by other authors (BOHL, 1987; MAGUIRE, 2002). Thus, the unequal sex ratio as a result of seasonal 


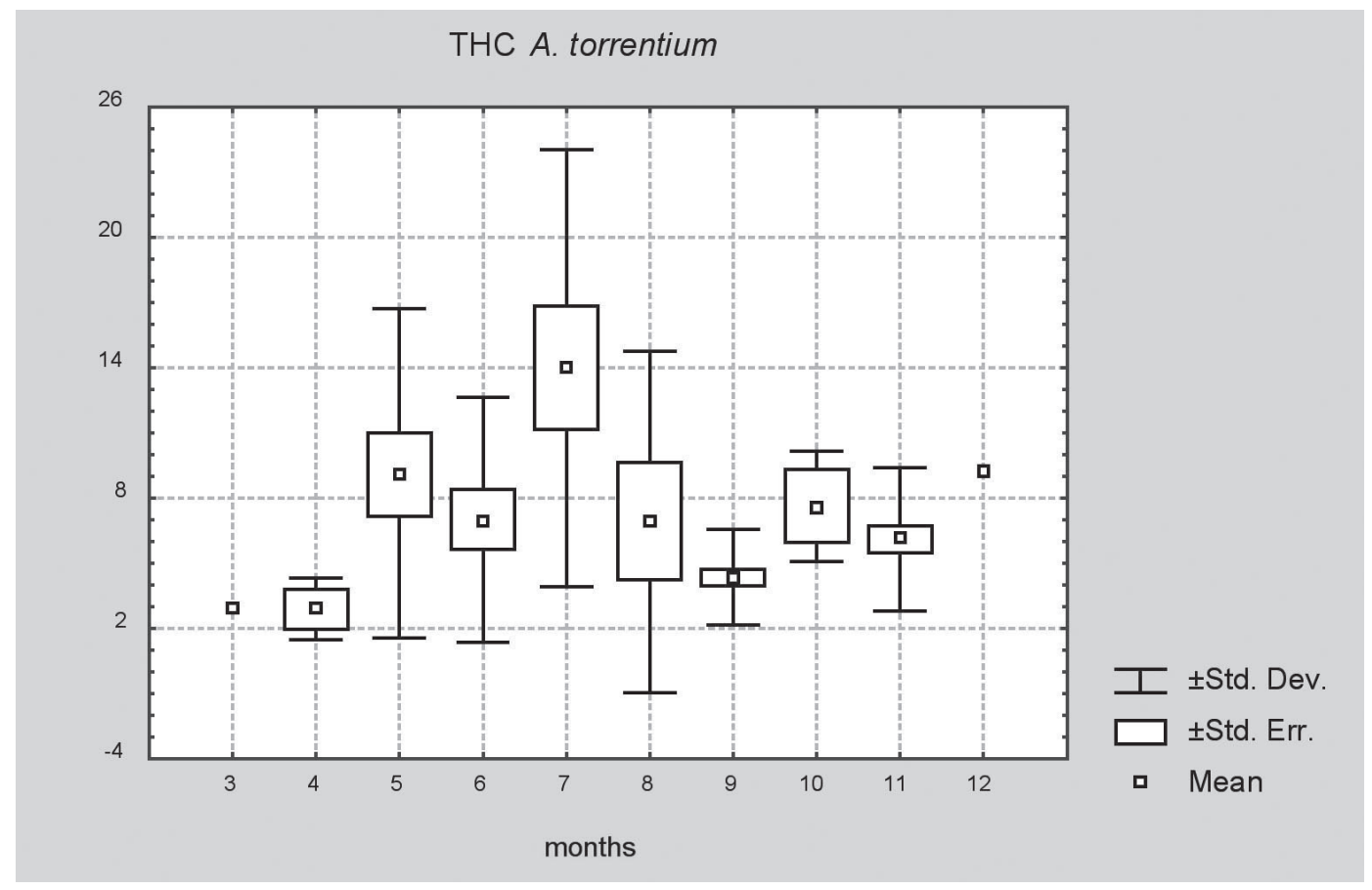

Figure 3

Standard deviations, mean and standard errors of total haemocyte counts (THC) in Austropotamobius torrentium from March to December, in Kraljevec Stream, Croatia.

Figure 3

Déviations standards, erreurs moyennes et standards des dépouillements d'hémocytes totaux (THC) d'Austropotamobius torrentium de mars à décembre, dans le ruisseau Kraljevec, Croatie.

inactivity of females during bearing eggs was also recorded in other species of Astacidae family (ACKEFORS, 1999; ALEKNOVICH, KULLESH and ABLOV, 1999).

Changes in the relative size of the hepatopancreas (hepatosomatic indices), gonads (gonadosomatic indices) and tail muscle (muscle indices) were detected in farmed as well as in wild crayfish populations (HUNER, LINDQVIST and KÖNÖNEN, 1988; HUNER, KÖNÖNEN and LINDQVIST, 1990; JUSSILA, 1997; YAMAGUCHI, 2001; CARMONAOSALDE et al., 2004). The higher hepatopancreas moisture content and at the same time lower relative hepatopancreas weight during the moulting period of males (from July to September) is the result of spending their energy reserves in the postmoult period as it was previously described by some authors (DAUPHIN-VILLEMANT, BÖCKING and SEDLMEIR, 1995; YAMAGUCHI, 2001). Moreover, most of the males caught during that period were already moulted and thereby consumed nutritients stored in hepatopancreas during the intermoult period. With approaching the mating period (October) wet hepatopancreas weight increased and moisture content decreased which is the opposite than what YAMAGUCHI (2001) and VIIKINKOSKI et al. (1995) found during the mating period. One possible explanation of this difference might be the small sample size used in our research. On the other hand, it is also possible that males accumulated energy in the hepatopancreas and testis at the same time because the energy demand of the spermatogenesis is very Iow (GHERARDI, 2002). Similarly to our findings, no clear relationship between the hepatopancreas and gonad indices was found in Sesarma intermedia males by KYOMO 
(1988). The energy accumulation in the testis is indicated by the slight increase of $\mathrm{Gi}_{\text {wet }}$ and the decrease of GM while approaching to mating period (Figures 1 and 2). KYOMO (1988) detected that the gonad index of males fluctuated all year round within a very small range, i.e. between 0.5 and $0.9 \%$ while in our study it fluctuated between 0.4 and $0.8 \%$. In the females $\mathrm{Hi}_{\text {wet }}$ and $\mathrm{HM}$ decreased by approaching the mating season in October while continuous and significant increase of $\mathrm{Gi}_{\text {wet }}$ and decrease of $\mathrm{GM}$ was detected during the period from May to October. These findings indicated that the relative hepatopancreas weight decreased with the increase of relative ovaries weight while energy accumulated in both organs although the energy accumulation is more intensive in ovaries (decrease of GM from 82.7 to $72 \%$ ). Many other authors also found an increase in the relative gonad weight with approaching to mating period (PALACIOS, IBARRA and RACOTTA, 2000; ZAPATA et al., 2003; CARMONA-OSALDE et al., 2004).

Seasonal changes in hepatosomatic and gonadosomatic indices were statistically confirmed in all tested parameters. Males and females differed significantly in hepatopancreas moisture content and relative gonad weight and this finding confirms the different energy demands of oogenesis and spermatogenesis (GHERARDI, 2002). Similarly to our results, HUNER, LINDQVIST and KÖNÖNEN (1988) also found no significant differences in the relative hepatopancreas weight between males and females. These findings probably reflect many important functions of this gland.

Female stone crayfish had significantly higher weight of abdominal muscle then males. This data is in agreement with the findings of HUNER, LINDQVIST and KÖNÖNEN (1988) for species Astacus astacus and Procambarus clarkii. The bigger tail muscle in females is connected with its role in bearing eggs. Decrease in the relative tail muscle weight of both males and females during the moulting and the mating periods (Figures 1 and 2) may reflect the higher level of activity during that period.

The positive correlation between organ weight and total body weight and negative between relative organ weight and total body weight also confirmed the findings of OBRADOVIĆ, SEKULIĆ and RAC (1988) on the same species. These results indicated that hepatopancreas, gonads and tail muscle relative weights do not increase proportionally with the total body weight. Similarly, HUNER, LINDQVIST and KÖNÖNEN (1988) found that the proportions of tail muscle and hepatopancreas do not increase geometrically with the increase of total body lengths.

We did not find significant differences in total heamocyte counts (THC) between males and females of the stone crayfish and as there are no data on sexual differences in this respect in other articles we assume that there are no sex differences in other species, either (JUSSILA, 1997; EVANS et al., 1999; JUSSILA et al., 1999; LE MOULLAC and HAFNER, 2000; YILDIZ and BENLI, 2004). Although THC is often used as an indicator of stress (JONES, 1999; YILDIZ and BENLI, 2004; EVANS et al., 1999) we agree with the opinion of JOHANSSON et al. (2000) that this parameter is not a reliable condition index, mainly because of great individual differences noticed during the counting of haemocytes. Differences in THC between months were not significant although mean THC-s were higher during the moulting period (Figure 3) which may be connected with the role of hemocytes in the tanning and mineralization of the exoskeleton after moulting. VACCA and FINGERMAN (1983) and HOSE et al. (1992) established that hyalinocyte number increased during moulting while granulocyte number grew during intermoult period. Significant changes in the ratio of different cell types during the year found in our research are in agreement with the findings of VACCA and FINGERMAN (1983) and HOSE et al. (1992). No significant differences in differential haemocyte counts of males and females found in our research confirmed the findings of CORNICK and STEWART (1978) in Homarus americanus. Haemocyte ratio similar to what we found was published by VASQUEZ et al. (1997) for freshwater shrimp Macrobrachium rosenbergii (70\% hyalinocytes, $20 \%$ granulocytes and $10 \%$ undifferentiated cells) while HARDY (1892) mentioned that Astacus 
fluviatilis has three times more hyalinocytes than granulocytes which is also in agreement with our findings for $A$. torrentium. On the other hand, marine Decapods have different haemocyte ratio (CORNICK and STEWART, 1978; HOSE, MARTIN and GERARD, 1990).

\section{CONCLUSIONS}

The annual cycle of the stone crayfish is characterized by changes in hepatosomatic and gonadosomatic indices. Gonadosomatic indices increased gradually with the approaching reproductive season while the changes in the hepatosomatic indices were not so clear. Hepatosomatic and gonadosomatic indices of males and females were significantly different because of different energy demands of oogenesis and spermatogenesis. Relative tail muscle weight is higher in females then in males. The weight of hepatopancreas, gonads and tail muscle is directly proportional to the total body weight but their ratio to the body weight is indirectly proportional to it. Total haemocyte counts did not change significantly during the year while the ratio of different cell types did. As the total and differential haemocyte counts show great individual differences they should not be used as reliable condition parameters. As the studied species is protected by law in Croatia and the population is located in a protected area of Nature Park Medvednica the number of specimens approved for sacrifice and analysis was small and the trends identified here need to be confirmed during a second year of the study.

\section{REFERENCES}

ACKEFORS H.E.G., 1999. Observations on the yearly life cycle of Astacus astacus in a small lake in Sweden. Freshwater Crayfish, 12, 413-429.

ALEKNOVICH A., KULLESH V., ABLOV S., 1999. Growth and size structure of narrowclawed crayfish Astacus leptodactylus Esch. in its eastern area. Freshwater Crayfish, 12, 550-554.

ANDERSON R.S., 1981. Comparative aspects of the structure and function of invertebrate and vertebrate leucocytes. In: RATCLIFFE N.A., ROWLEY A.F. (eds.), Invertebrate Blood Cells, Vol. 2, 629-640, Academic Press.

BAUCHAU A.G., 1981. 12. Crustaceans. In: RATCLIFFE N.A., ROWLEY A.F (eds.) Invertebrate Blood Cells, Vol. 2, 385-420, Academic Press.

BOHL E., 1987. Comparative studies on crayfish brooks in Bavaria (Astacus astacus L., Austropotamobius torrentium Schr.). Freshwater Crayfish, 7, 287-294.

CARMONA-OSALDE C., RODRÍGUEZ-SERNA M., OLVERA-NOVOA M.A., GUTIÉRREZYURRITA P.J., 2004. Effect of density and sex ratio on gonad development and spawning in the crayfish Procambarus llamasi. Aquaculture, in Press.

CORNICK J.W., STEWART J.E., 1978. Lobster (Homarus americanus) hemocytes: Classification, differential counts, and associated agglutinin activity. J. Invertebrate Pathol., 31, 194-203.

DAUPHIN-VILLEMANTC., BÖCKING D., SEDLMEIRD., 1995. Regulation of steroidogenesis in crayfish molting glands: involvement of protein synthesis. Molecular and Cellular Endocrinol., 109(1), 97-103.

EVANS L.H., FOTEDAR S., FAN A., JONES B., 1999. Investigation of idiopathic muscle necrosis and circulating hemocytes in the freshwater crayfish Cherax tenuimanus exposed to acute and chronic stressors. Freshwater Crayfish, 12, 356-370.

FOTEDAR R., 1998. Effect of dietary protein and lipid source on the growth, survival, condition indices, and body composition of marron, Cherax tenuimanus (Smith). Aquaculture, 230, 439-455. 
GHERARDI F., 2002. Behaviour. In: HOLDICH D.M. (ed.), Biology of Freshwater Crayfish, 258-259, Blackwell Science.

HARDY W.B., 1892. The blood corpuscules of the Crustacea, together with a suggestion as to the origin of the crustacean fibrin-ferment. J. Physiol., 13, 165-190.

HOSE J.E., MARTIN G.G., GERARD A.S., 1990. A decapod hemocyte classification scheme integrating morphology, cytochemistry, and function. Biol. Bull., 178, 3345.

HOSE J.E., MARTIN G.G., TIU S., McRELL N., 1992. Patterns of hemocyte production and release throughout the molt cycle in the peneid shrimp Sicyonia ingentis. Biol. Bull., 183, 185-199.

HUNER J.V., KÖNÖNEN H., LINDQVIST O.V., 1990. Variation in body composition and exoskeleton mineralisation as functions of the molt and reproductive cycles of the noble crayfish, Astacus astacus (Astacidae, Decapoda), from a pond in central Finland. Comp. Bochem. Physiol., 96A(1), 235-240.

HUNER J.V., LINDQVIST O.V., KÖNÖNEN H., 1988. Comparison of morphology and edible tissues of two important commercial crayfishes, the noble crayfish, Astacus astacus Linné, and the red swamp crayfish, Procambarus clarkii (Girard) (Decapoda, Astacidae and Cambaridae). Aquaculture, 68, 45-57.

JOHANSSON M.W., KEYSER P., SRITUNYALUCKSANA K., SÖDERHÄLL K., 2000. Crustacean haemocytes and hematopoisis. Aquaculture, 191, 45-52.

JONES B., 1999. Cellular response to injury in spiny lobsters. Proceedings, International symposium on lobster health management, 9-17, Adelaide.

JUSSILA J., 1997. Physiological responses of Astacid and Parastacid crayfishes (Crustacea: Decapoda) to conditions of intensive culture. Doctoral Dissertation, University of Kuopio, Finland, 17-137.

JUSSILA J., MANNONEN A., 1997. Marron (Cherax tenuimanus) and noble crayfish (Astacus astacus) hepatopancreas energy and its relationship to moisture content. Aquaculture, 149, 157-161.

JUSSILA J., PAGANINI M., MANSFIELD S., EVANS L.H., 1999. On physiological responses, plasma glucose, total hemocyte counts and dehydration, of marron Cherax tenuimanus (Smith) to handling and transportation under simulated conditions. Freshwater Crayfish, 12, 155-167.

KYOMO J., 1988. Analysis of the relationship between gonads and hepatopancreas in males and females of the crab Sesarma intermedia, with reference to resource use and reproduction. Marine Biology, 97, 87-93.

LAURENT P.J., 1988. Austropotamobius pallipes and A. torrentium, with observations on their interactions with other species in Europe. In: HOLDICH D.M., LOWERY R.S. (eds.), Freshwater crayfish, 341-364, University Press, Cambridge.

LE MOULLAC G., HAFFNER P., 2000. Environmental factors affecting immune responses in Crustacea. Aquaculture, 191, 121-131.

MAGUIRE I., 2002. Family Astacidae in north-west Croatia. Doctoral Thesis (in Croatian with English abstract), Faculty of Science, University of Zagreb, 12-13.

MANNONEN A., HENTTONEN P., 1995. Some observations on the condition of crayfish (Astacus astacus (L.) in a river affected by peat mining in central Finland. Freshwater Crayfish, 10, 274-281.

MARTIN G.G., GRAVES B.L., 1985. Fine structure and classification of shrimp hemocytes. J. Morphol., 185, 339-348. 
MARTIN G.G., HOSE J.E., 1992. Vascular elements and blood (Hemolymph). In: Microscopic Anatomy of Invertebrates: Decapod Crustacea Vol. 10, 117-146, Wiley-Liss. Inc.

MIX M.C., SPARKS A.K., 1980. Hemocyte classification and differential counts in the dungeness crab, Cancer magister. J. Invertebrate Pathol., 35, 134-143.

NARODNE NOVINE, 30, 1994. Zakon o Zaštiti prirode.

NARODNE NOVINE, 76, 1998 Pravilnik o zaštiti riječnih rakova.

OBRADOVIĆ J., SEKULIĆ B., RAC M., 1988. Muscle and hepatopancreas participation in the body weight of the crayfish Austropotamobius torrentium. Aquaculture, 72 (3-4), 329-339.

PALACIOS E., IBARRA A.M., RACOTTA I.S., 2000. Tissue biochemical composition in relation to multiple spawning in wild and pond-reared Penaeus vannamei broodstock. Aquaculture, 185, 353-371.

TSVETNENKO E., BROWN J., GLENCROSS B.D., EVANS L.H., 1999. Measures of condition in dietary studies on western rock lobster post-pueruli. Proceedings, International symposium on lobster health management, Adelaide, 100-109.

VACCA L.L., FINGERMAN M., 1983. The roles of hemocytes in tanning during the molting cycle: a histochemical study of the fiddler crab, Uca pugilator. Biol. Bull., 165, 758777.

VÁZQUEZ L., PÉREZ A., MILLÁN D., AGUNDIS C., MARTIN G., COOPER E.L., LASCURAIN R., ZENTENO E., 1997. Morphology of hemocytes from the freshwater prawn Macrobrachium rosenbergii. J. Morphol., 234, 147-153.

VIIKINKOSKI T., HENTTONEN P., MATINVESI J., KÖNÖNEN H., SUNTIOINEN S. 1995. The physiological condition and edibility of noble crayfish (Astacus astacus (L.) in warm waste waters of a steel works in northwest Finland. Freshwater Crayfish, 10, 304-321.

WOOD P.J., VISENTIN L.P., 1967. Histological and histochemical observations of the hemolymph cells in the crayfish, Orconectes virilis. J. Morphol., 123, 559-568.

YAMAGUCHI T., 2001. Seasonal change of the hepatopancreas index in the males of the fiddler crab, Uca lactea. Crustaceana, 74(7), 627-634.

YILDIZ H.Y., BENLI C.K., 2004. Nitrite toxicity to crayfish, Astacus leptodactylus, the effects of sublethal nitrite exposure on hemolymph nitrite, total haemocyta counts, and hemolymph glucose. Ecotoxicol. Environm. Safety: Article in press.

ZAPATA V., LÓPEZ GRECO L.S., MEDESANI D., RODRÍGUEZ E.M., 2003. Ovarian growth in the crab Chasmagnathus granulata induced by hormones and neuroregulators throughout the year. In vivo and in vitro studies. Aquaculture, 224, 339-352. 
